\title{
Differences in Emotional Labor and Job Attitude of Aged Care Facility Workers by Sociodemographic Characteristics
}

\author{
So-Jeong Shin $^{1}$ \\ ${ }^{1}$ Professor, Department of Rehabilitation for Dementia, Catholic Kwandong University, Republic of \\ Korea,ssj5388@naver.com
}

\begin{abstract}
The purpose of this study is to investigate on the difference of emotional labor and job attitude by the sociodemographic characteristics of aged care facility workers. The subjects of this study were 135 aged care facility workers in K-city and D-city of Gangwon-do. As for the analysis method, frequency analysis, reliability analysis, and correlation analysis were performed using the SPSS program, and t-test and one-way ANOVA were performed on the differences between groups. The results of the study are as follows: first, upon examining the differences in emotional labor by sociodemographic characteristics of aged care facility workers, significant differences were found among groups in the type of facility but no differences were found among groups in sex, age, and job position. Second, upon examining the differences in job attitudes by sociodemographic characteristics of aged care facility workers, significant differences were found between groups in age, but there was no difference between groups in gender, job position, and facility type. This study is intended to provide foundational data for the development of programs to strengthen the capabilities of aged care facility workers in the field of social welfare services by identifying the differences in emotional labor and job attitude of aged care facility workers.
\end{abstract}

Keywords: Aged Care Facility Worker, Emotional Labor, Job Attitude, Job Satisfaction, Organizational Commitment

\section{Introduction}

\subsection{Necessity of Research}

The recent scientific developments and economic growth have extended life expectancies. As Korea becomes an aged society with $14.7 \%(7,650,408$ persons $)$ of the entire population $(51,826,029$ persons $)$ aged over 65 (Ministry of the Interior and Safety, 2018), there has been a rapid increase in the number of elderly citizens who are unable to live by themselves due to geriatric diseases[1]. Therefore, with the ageing society, the role of and the demand for aged care facility workers have increased, and geriatric diseases and problems that occur to the elderly have also been diversifying.

An aged care facility worker supports household or physical services at aged care facilities for the elderly who are unable to carry out their daily lives independently due to geriatric conditions such as dementia and cerebrovascular diseases[2]. Also, various conflicts and phenomena within the workplace regarding emotional labor have been highlighted. Emotion is expressing what one feels about something in their interaction with others[3][4].

What is emotional labor? It was initially used for people in the service sector, such as flight attendants, and it is understood as the process of converting inherent human emotions into an exchangeable value

Received: August 31, 2020; $1^{\text {st }}$ Review Result: October 17, 2020; $2^{\text {nd }}$ Review Result: November 30, 2020 Accepted: December 28, 2020 
and extracting surplus value by generating profits from it[5][6].

However, the focus on emotional labor is not on the emotion itself, but on the action that is passed on externally in the process of the aged care facility worker providing service, and the key element of emotional labor is deemed to be the action, not the emotion. Therefore, emotional labor has been defined as the appropriate expression of emotions in accordance with display rules. In addition to the surface acting and deep acting of workers that are required to express emotions as trained by the customer or the organization, genuine acting, which is the effort taken to match this with actual emotions, is included as a sub-dimension of emotional labor. It is also argued that explaining emotional labor as only surface acting and deep acting is overlooking the face that workers experience and express emotions. Genuine acting is defined as the expression of the heart which includes sincerity, and it is explained as the process where the emotion that the worker actually feels and experiences concurs with the emotions that are prescribed as desirable by the organization. As service is a repetition of interactions in a relationship, workers would try to deliver their genuine feelings, and it is argued that as the emotions experienced and the emotions expressed align, no separate emotional labor would be required[7].

A review of existing studies on the job attitude of aged care facility workers as a key variable of emotional labor showed that a 'job' is the collection of the equivalent position of important tasks and it refers to the duty that is assigned to and continuously performed by the worker by their job position. Sociodemographically, job attitude is defined as the relatively continual beliefs, emotions, and behavioral tendencies toward a particular perceptual object[8].

Therefore, job attitude refers to the attitude related to the individual's job among the countless attitudes they have, and it's not only a personal characteristic of the worker but also the deep, internal feeling that the worker has when they think about the job they are responsible for. The individual's attitude is determined by feeling, which is an emotional element, and by reason, which is an evaluative or cognitive element. Job attitude is not only a personal characteristic of an employee, but it also varies depending on the evaluation of duties, the characteristics of tasks required for those duties, and the level of loyalty or affection for the organization. As such, the collection of these emotions, beliefs and thoughts about a job is referred to as job attitude[9].

Furthermore, given that job attitude plays an important role in predicting organizational performance and integrating the objectives of the individual and the organization, what is important is finding what causes the individual attitude to change and the solution. Desirable attitudes, such as job satisfaction and organizational commitment, serve a positive function of improving organizational performance, but undesirable attitudes, such as job dissatisfaction and job stress, may create an adverse function including tardiness or absences. Therefore, it is crucial to understand how to change the attitude of the members of the organization in a desirable direction for the sake of the organization's productivity[10].

As seen above, existing studies show that the higher the aged care facility worker's perception of emotional dissonance, the lower their job satisfaction, and the deeper their exhaustion and depersonalization[11]. It has been reported that aged care facility workers are struggling between the emotions expected by the organization and their actual emotions while performing tasks that require contact with customers. The more diverse the service duties performed in service content, the more diverse the emotions that aged care facility workers are expected to express, and continually expressing these conformed emotions become a stress factor for employees[12].

The results of these existing studies highlight the need to research the difference in emotional labor and job attitude by sociodemographic characteristics of aged care facility workers. Aged care facility workers are professionals who are most closely working with the elderly, but they are exposed to emotional labor, unclear job performance roles, and low self-esteem. There are some case studies on aged care facility workers, but studies on emotional labor and job attitude are very insufficient. Therefore, this study seeks to identify the effect on emotional labor and job attitude for aged care facility workers and call for foundational data regarding the successful job attitude and role of aged care facility 
workers and the development of capability enhancement programs.

\subsection{Research Question}

The purpose of this study is to investigate the differences in emotional labor and job attitude of aged care facility workers. The specific research questions are as follows:

1. what is the difference in emotional labor by the sociodemographic characteristics of aged care facility workers?

2. what is the difference in job attitude by the sociodemographic characteristics of aged care facility workers?

\section{Research Method}

\subsection{Research Subjects}

This study was conducted on aged care facility workers in K-city and D-city of Gangwon-do between 10 August 2018 and 20 October 2018. Questionnaires were self-administered after thoroughly explaining the purpose of the questionnaire to subjects. A total of 135 questionnaires were collected and used for analysis.

\subsection{Research Tools}

The tools used for this study consist of 4 questions on sociodemographic characteristics, 9 questions on emotional labor, and 16 questions on job attitude. Sociodemographic characteristics include gender, job position, and type of facility. The emotional labor scale used by Kim Jong-Pil to measure the emotional labor of aged care facility workers consists of 9 questions with 3 questions on the frequency of emotional display, 3 questions on the attentiveness to display rules, and 3 questions on emotional dissonance, and each question was measured using Likert's 5-point scale[13]. The job attitude scale used by Yang Jin-Man to measure the job attitude consists of 16 questions with 8 questions on job satisfaction and 8 questions on organizational commitment, and each question was measured using Likert's 5-point scale[14].

\subsection{Reliability}

Upon verifying the reliability of each variable used in this study, high reliability was found in emotional labor (.837) and job attitude (.887). The reliability of each measurement tool exceeded the minimum Cronbach's $\alpha$ value of .60, demonstrating that there is no problem with reliability. Detailed results of the reliability analysis of major variables are shown in [Table 1].

[Table 1] Reliability of Major Variables

\begin{tabular}{|c|c|c|}
\hline Classification & Number of Questions & Cronbach's $\alpha$ \\
\hline Emotional labor & 9 & .837 \\
\hline Job attitude & 16 & .887 \\
\hline
\end{tabular}




\subsection{Data Processing and Analysis Method}

Data collected for this study were processed using the SPSS 22.0 program and were verified at the significance level of 5\%, and the reliability of each research tool was analyzed using Cronbach's $\alpha$ coefficient. A frequency analysis was conducted for the sociodemographic characteristics of aged care facility workers. A correlation analysis was conducted on the emotional labor and job attitude of aged care facility workers, and t-test and one-way ANOVA were performed to identify the differences in emotional labor and job attitude by sociodemographic characteristics.

\section{Results}

\subsection{Sociodemographic Characteristics}

Upon examining the sociodemographic characteristics of the research subjects, there was a higher proportion of females in aged care facility workers with 29 male subjects $(21.5 \%)$ and 106 female subjects $(78.5 \%)$. In age, 50's and over was the most common with 74 subjects $(54.8 \%)$, followed by 39 subjects in their 40's (28.9\%), and 22 subjects in their 30's (16.\%). In job position, aged care facility worker was the most common with 89 subjects $(65.9 \%)$, followed by 27 social workers $(20.0 \%), 12$ nursing assistants $(8.9 \%)$, and 7 nurses $(5.2 \%)$. In facility type, day care facility was the most common with 120 subjects $(88.9 \%)$, followed by short-term facility with 10 subjects (7.4\%), and nursing homes with 5 subjects $(3.7 \%)$. The analysis results of aged care facility workers' sociodemographic characteristics are shown in [Table 2].

[Table 2] Sociodemographic Characteristics

\begin{tabular}{|c|c|c|c|}
\hline & & \multicolumn{2}{|c|}{ Total $(\mathrm{N}=135)$} \\
\hline \multicolumn{2}{|c|}{ Classification } & \multirow{2}{*}{$\begin{array}{c}\text { Frequency } \\
29\end{array}$} & \multirow{2}{*}{$\begin{array}{c}\text { Percentage }(\%) \\
21.5\end{array}$} \\
\hline \multirow{2}{*}{ Gender } & Male & & \\
\hline & Female & 106 & 78.5 \\
\hline \multirow{3}{*}{ Age } & 30 's & 22 & 16.3 \\
\hline & 40 's & 39 & 28.9 \\
\hline & 50 's and over & 74 & 54.8 \\
\hline \multirow{4}{*}{ Job position } & Social worker & 27 & 20.0 \\
\hline & Nurse & 7 & 5.2 \\
\hline & Nursing assistant & 12 & 8.9 \\
\hline & Aged care facility worker & 89 & 65.9 \\
\hline \multirow{3}{*}{ Facility type } & Day care facility & 120 & 88.9 \\
\hline & Short-term care facility & 10 & 7.4 \\
\hline & Nursing home & 5 & 3.7 \\
\hline
\end{tabular}

\subsection{Descriptive Statistics of Major Variables}

The measurement variables for the major variables of aged care facility workers were measured on a 
5-point scale. In the sub-factors of emotional labor, the frequency of emotional display $(\mathrm{M}=3.34)$ was the highest, followed by the attentiveness to display rules $(M=3.09)$ and emotional dissonance $(M=2.66)$. In the sub-factors of job attitude, organizational commitment $(\mathrm{M}=3.80)$ was higher than job satisfaction $(\mathrm{M}=3.52)$, which were all higher than average. The results of the descriptive statistics of major variables of aged care facility workers are shown in [Table 3].

[Table 3] Descriptive Statistics of Major Variables

\begin{tabular}{|c|c|c|c|c|c|c|}
\hline \multicolumn{2}{|c|}{ Classification } & \multirow{2}{*}{$\begin{array}{c}\mathrm{N} \\
135\end{array}$} & \multirow{2}{*}{$\begin{array}{c}\begin{array}{c}\text { Minimum } \\
\text { value }\end{array} \\
1.33\end{array}$} & \multirow{2}{*}{$\begin{array}{c}\begin{array}{c}\text { Maximum } \\
\text { value }\end{array} \\
5.00\end{array}$} & \multirow{3}{*}{$\begin{array}{c}\mathrm{M} \\
3.34 \\
3.09\end{array}$} & \multirow{3}{*}{$\begin{array}{l}\text { SD } \\
.94 \\
.79\end{array}$} \\
\hline \multirow{3}{*}{$\begin{array}{l}\text { Emotional } \\
\text { labor }\end{array}$} & $\begin{array}{c}\text { Frequency of } \\
\text { emotional display }\end{array}$ & & & & & \\
\hline & $\begin{array}{l}\text { Attentiveness to } \\
\text { display rules }\end{array}$ & 135 & 1.00 & 5.00 & & \\
\hline & $\begin{array}{l}\text { Emotional } \\
\text { dissonance }\end{array}$ & 135 & 1.00 & 4.67 & 2.66 & .90 \\
\hline \multirow{2}{*}{$\begin{array}{c}\text { Job } \\
\text { attitude }\end{array}$} & Job satisfaction & 135 & 2.13 & 5.00 & 3.52 & .45 \\
\hline & $\begin{array}{l}\text { Organizational } \\
\text { commitment }\end{array}$ & 135 & 1.57 & 5.57 & 3.80 & .62 \\
\hline
\end{tabular}

\subsection{Correlation Between Major Variables}

Upon examining the correlation between the emotional labor and job attitude of aged care facility workers, the frequency of emotional display and the attentiveness to display rules $(\mathrm{r}=.786, \mathrm{p}<.01)$, which are sub-factors of emotional labor perceived by aged care facility workers, and job satisfaction and organizational commitment $(\mathrm{r}=.711, \mathrm{p}<.01)$, which are sub-factors of job attitude, were found to have a high level of positive correlation. On the other hand, the frequency of emotional display and job satisfaction $(\mathrm{r}=.711, \mathrm{p}<.01)$ were found to have a low level of negative correlation, and the attentiveness to display rules and job satisfaction $(\mathrm{r}=-.294, \mathrm{p}<.01)$. These results demonstrate that each correlation coefficient value has a relationship with variables under a level of statistical significance. The results of the correlation analysis between variables are shown in [Table 4].

[Table 4] Correlation Between Major Variables

\begin{tabular}{|c|c|c|c|c|c|c|}
\hline \multirow{2}{*}{\multicolumn{2}{|c|}{ Classification }} & \multicolumn{3}{|c|}{ Emotional labor } & \multicolumn{2}{|c|}{ Job attitude } \\
\hline & & \multirow{2}{*}{$\begin{array}{c}\begin{array}{c}\text { Frequency of } \\
\text { emotional } \\
\text { display }\end{array} \\
1\end{array}$} & $\begin{array}{c}\text { Attentiveness } \\
\text { to display } \\
\text { rules }\end{array}$ & $\begin{array}{l}\text { Emotional } \\
\text { dissonance }\end{array}$ & $\begin{array}{c}\text { Job } \\
\text { satisfaction }\end{array}$ & $\begin{array}{c}\text { Organizational } \\
\text { commitment }\end{array}$ \\
\hline \multirow{3}{*}{$\begin{array}{c}\text { Emotional } \\
\text { labor }\end{array}$} & $\begin{array}{l}\text { Frequency of } \\
\text { emotional display }\end{array}$ & & & & & \\
\hline & $\begin{array}{l}\text { Attentiveness to } \\
\text { display rules }\end{array}$ & $.786 * *$ & 1 & & & \\
\hline & $\begin{array}{l}\text { Emotional } \\
\text { dissonance }\end{array}$ & $.479 * *$ & $.665 * *$ & 1 & & \\
\hline \multirow{2}{*}{$\begin{array}{c}\text { Job } \\
\text { attitude }\end{array}$} & Job satisfaction & $-.298 * *$ & $-.294 * *$ & $-.296^{*}$ & 1 & \\
\hline & $\begin{array}{c}\text { Organizational } \\
\text { commitment }\end{array}$ & $.347 * *$ & $.272 * *$ & $.209 * *$ & $.711^{* *}$ & 1 \\
\hline
\end{tabular}

$* \mathrm{p}<.05, * * \mathrm{p}<.01$ 


\subsection{Differences in Emotional Labor and Job Attitude by Sociodemographic Characteristics}

\subsubsection{Difference in Emotional Labor and Job Attitude by Gender}

Upon examining the difference in emotional labor and job attitude by the gender of aged care facility workers, the equality of variance was assumed as Levene's test was $\mathrm{p}=.055 \sim .093$ for emotional labor and $\mathrm{p}=.220 \sim .298$ for job attitude. There was no statistically significant difference in emotional labor by the gender of aged care facility worker in the frequency of emotional display $(t=.397, \mathrm{p}>.05)$, the attentiveness to display rules $(\mathrm{t}=.229, \mathrm{p}>.05)$ and emotional dissonance $(\mathrm{t}=.845, \mathrm{p}>.05)$. There was also no difference in means under the level of statistical significance in job attitude for both job satisfaction $(\mathrm{t}=1.543, \mathrm{p}>.05)$ and organizational commitment $(\mathrm{t}=1.781, \mathrm{p}>.05)$. The fact that there is no difference in mean for emotional labor and job attitude as perceived by aged care facility workers implies that it is at the same level regardless of gender. The results of examining the difference in emotional labor and job attitude by the gender of aged care facility workers are shown in [Table 5].

[Table 5] Difference in Emotional Labor and Job Attitude by Gender

\begin{tabular}{|c|c|c|c|c|c|c|c|}
\hline & \multicolumn{2}{|l|}{ Classification } & \multicolumn{2}{|c|}{ Levene test } & \multirow{2}{*}{$\begin{array}{c}\text { M } \\
3.39\end{array}$} & SD & $\mathrm{t}(\mathrm{p})$ \\
\hline \multirow{6}{*}{$\begin{array}{c}\text { Emotional } \\
\text { labor }\end{array}$} & \multirow{2}{*}{$\begin{array}{c}\text { Frequency of } \\
\text { emotional } \\
\text { display }\end{array}$} & Male & \multirow{2}{*}{8.251} & \multirow{2}{*}{.055} & & .63 & \multirow{2}{*}{$.397(.760)$} \\
\hline & & Female & & & 3.33 & 1.01 & \\
\hline & \multirow{2}{*}{$\begin{array}{l}\text { Attentiveness } \\
\text { to display } \\
\text { rules }\end{array}$} & Male & \multirow{2}{*}{2.857} & \multirow{2}{*}{.093} & 3.12 & .64 & \multirow{2}{*}{$.229(.819)$} \\
\hline & & Female & & & 3.08 & .83 & \\
\hline & \multirow{2}{*}{$\begin{array}{l}\text { Emotional } \\
\text { dissonance }\end{array}$} & Male & \multirow{2}{*}{8.218} & \multirow{2}{*}{.075} & 2.79 & 1.13 & \multirow{2}{*}{$.845(.400)$} \\
\hline & & Female & & & 2.63 & .83 & \\
\hline \multirow{3}{*}{$\begin{array}{c}\text { Job } \\
\text { attitude }\end{array}$} & \multirow{2}{*}{$\begin{array}{c}\text { Job } \\
\text { satisfaction }\end{array}$} & Male & \multirow{2}{*}{1.090} & \multirow{2}{*}{.298} & 3.64 & .53 & \multirow{2}{*}{$1.543(.125)$} \\
\hline & & Female & & & 3.49 & .43 & \\
\hline & $\begin{array}{l}\text { Organizational } \\
\text { commitment }\end{array}$ & $\begin{array}{c}\text { Male } \\
\text { Female }\end{array}$ & 1.522 & .220 & 3.98 & .53 & $1.781(.077)$ \\
\hline
\end{tabular}

\subsubsection{Difference in Emotional Labor and Job Attitude by Age}

Variance analysis was conducted to examine the difference in emotional labor and job attitude by the age of aged care facility workers. The equality of variance was assumed as Levene's test was $\mathrm{p}=.060 \sim .267$ for emotional labor and $\mathrm{p}=.205 \sim .744$ for job attitude. There was no statistically significant difference in emotional labor by the age of aged care facility worker in the frequency of emotional display $(\mathrm{t}=2.140, \mathrm{p}>.05)$, the attentiveness to display rules $(\mathrm{t}=1.215, \mathrm{p}>.05)$ and emotional dissonance $(\mathrm{t}=.300, \mathrm{p}>.05)$. In job attitude, a statistically significant difference was found between groups in the 40 's and the 50's and over for job satisfaction $(\mathrm{t}=3.955, \mathrm{p}>.05)$, but there was no statistically significant 
difference found between groups in the difference in mean for organizational commitment $(t=1.781$, $\mathrm{p}>.05)$. There was a meaningful difference in the job satisfaction of aged care facility workers between groups in the 40's and the 50's and over, and the fact that there is no difference in mean for emotional labor and job attitude implies that it is at the same level regardless of age. The results of examining the difference in emotional labor and job attitude by the age of aged care facility workers are shown in [Table 6].

[Table 6] Difference in Emotional Labor and Job Attitude by Age

\begin{tabular}{|c|c|c|c|c|c|c|}
\hline \multicolumn{3}{|c|}{ Classification } & \multirow{2}{*}{$\begin{array}{c}\mathrm{M} \\
3.30\end{array}$} & \multirow{2}{*}{$\begin{array}{l}\text { SD } \\
.63\end{array}$} & \multirow{2}{*}{ Levene test } & \multirow{2}{*}{$\begin{array}{c}F(p) \\
\text { Scheffe }\end{array}$} \\
\hline \multirow{9}{*}{$\begin{array}{l}\text { Emotional } \\
\text { labor }\end{array}$} & \multirow{3}{*}{$\begin{array}{c}\text { Frequency of } \\
\text { emotional } \\
\text { display }\end{array}$} & 30 's(a) & & & & \\
\hline & & 40 's(b) & 3.10 & 1.02 & \multirow[t]{2}{*}{$\mathrm{p}=.060$} & \multirow[t]{2}{*}{$2.140(.122)$} \\
\hline & & 50 's and over(c) & 3.48 & .95 & & \\
\hline & \multirow{3}{*}{$\begin{array}{l}\text { Attentiveness } \\
\text { to display } \\
\text { rules }\end{array}$} & 30’s(a) & 3.07 & .59 & \multirow{3}{*}{$\mathrm{p}=.267$} & \multirow{3}{*}{$1.215(.300)$} \\
\hline & & 40 ’s(b) & 2.94 & .88 & & \\
\hline & & 50's and over(c) & 3.18 & .79 & & \\
\hline & \multirow{3}{*}{$\begin{array}{l}\text { Emotional } \\
\text { dissonance }\end{array}$} & 30 's(a) & 2.68 & 1.10 & \multirow{3}{*}{$\mathrm{p}=.072$} & \multirow{3}{*}{$.300(.742)$} \\
\hline & & 40 ’s(b) & 2.57 & 1.06 & & \\
\hline & & 50 's and over(c) & 2.71 & .75 & & \\
\hline \multirow{6}{*}{$\begin{array}{c}\text { Job } \\
\text { attitude }\end{array}$} & \multirow{3}{*}{$\begin{array}{c}\text { Job } \\
\text { satisfaction }\end{array}$} & 30 's(a) & 3.55 & .39 & \multirow{3}{*}{$\mathrm{p}=.205$} & \multirow{3}{*}{$\begin{array}{c}3.955 *(.021) \\
b>c\end{array}$} \\
\hline & & 40 ’s(b) & 3.68 & .32 & & \\
\hline & & 50 's and over(c) & 3.43 & .50 & & \\
\hline & \multirow{3}{*}{$\begin{array}{l}\text { Organizational } \\
\text { commitment }\end{array}$} & 30 's(a) & 3.68 & .55 & \multirow{3}{*}{$\mathrm{p}=.744$} & \multirow{3}{*}{$1.253(.289)$} \\
\hline & & 40 ’s(b) & 3.92 & .62 & & \\
\hline & & 50 's and over(c) & 3.77 & .65 & & \\
\hline
\end{tabular}

$* \mathrm{p}<.05, * * \mathrm{p}<.01, * * * \mathrm{p}<.001$

\subsubsection{Difference in Emotional Labor and Job Attitude by Job Position}

Variance analysis was conducted to examine the difference in emotional labor and job attitude by the job position of aged care facility workers. The equality of variance was assumed as Levene's test was $\mathrm{p}=.065 \sim .211$ for emotional labor and $\mathrm{p}=.282 \sim .844$ for job attitude. There was no statistically significant difference in emotional labor by the job position of aged care facility worker in the frequency of emotional display ( $\mathrm{t}=1.653, \mathrm{p}>.05)$, the attentiveness to display rules $(\mathrm{t}=1.578, \mathrm{p}>.05)$ and emotional dissonance $(\mathrm{t}=1.394, \mathrm{p}>.05)$. There was also no difference in means under the level of statistical significance in job attitude for both job satisfaction $(\mathrm{t}=.873, \mathrm{p}>.05)$ and organizational commitment $(t=.296, p>.05)$. The fact that there is no difference in mean for emotional labor and job attitude as perceived by aged care facility workers implies that it is at the same level regardless of job position. The results of examining the difference in emotional labor and job attitude by the job position of aged care facility workers are shown in [Table 7]. 
[Table 7] Difference in Emotional Labor and Job Attitude by Job Position

\begin{tabular}{|c|c|c|c|c|c|c|}
\hline \multicolumn{3}{|c|}{ Classification } & \multirow{2}{*}{$\begin{array}{c}\mathrm{M} \\
3.41\end{array}$} & \multirow{2}{*}{$\begin{array}{l}\text { SD } \\
.52\end{array}$} & \multirow[t]{2}{*}{ Levene test } & \multirow[t]{2}{*}{$\begin{array}{c}F(p) \\
\text { Scheffe }\end{array}$} \\
\hline \multirow{12}{*}{$\begin{array}{l}\text { Emotional } \\
\text { labor }\end{array}$} & \multirow{4}{*}{$\begin{array}{c}\text { Frequency of } \\
\text { emotional } \\
\text { display }\end{array}$} & Social worker(a) & & & & \\
\hline & & Nurse(b) & 2.76 & .62 & \multirow{3}{*}{$\mathrm{p}=.065$} & \multirow{3}{*}{$1.653(.180)$} \\
\hline & & Nursing assistant(c) & 3.72 & .91 & & \\
\hline & & $\begin{array}{l}\text { Aged care facility } \\
\text { worker(d) }\end{array}$ & 3.31 & 1.04 & & \\
\hline & \multirow{4}{*}{$\begin{array}{l}\text { Attentiveness } \\
\text { to display } \\
\text { rules }\end{array}$} & Social worker(a) & 3.27 & .60 & \multirow{4}{*}{$\mathrm{p}=.118$} & \multirow{4}{*}{$1.578(.198)$} \\
\hline & & Nurse(b) & 3.14 & .46 & & \\
\hline & & Nursing assistant(c) & 3.41 & .78 & & \\
\hline & & $\begin{array}{l}\text { Aged care facility } \\
\text { worker(d) }\end{array}$ & 2.99 & .85 & & \\
\hline & \multirow{4}{*}{$\begin{array}{l}\text { Emotional } \\
\text { dissonance }\end{array}$} & Social worker(a) & 2.77 & .70 & \multirow{4}{*}{$\mathrm{p}=.211$} & \multirow{4}{*}{$1.394(.248)$} \\
\hline & & Nurse(b) & 3.14 & .95 & & \\
\hline & & Nursing assistant(c) & 2.88 & 1.07 & & \\
\hline & & $\begin{array}{l}\text { Aged care facility } \\
\text { worker(d) }\end{array}$ & 2.56 & .92 & & \\
\hline \multirow{8}{*}{$\begin{array}{c}\text { Job } \\
\text { attitude }\end{array}$} & \multirow{5}{*}{$\begin{array}{c}\text { Job } \\
\text { satisfaction }\end{array}$} & Social worker(a) & 3.50 & .43 & \multirow{4}{*}{$\mathrm{p}=.844$} & \multirow{4}{*}{$.873(.457)$} \\
\hline & & Nurse(b) & 3.58 & .43 & & \\
\hline & & Nursing assistant(c) & 3.33 & .51 & & \\
\hline & & $\begin{array}{l}\text { Aged care facility } \\
\text { worker(d) }\end{array}$ & 3.55 & .45 & & \\
\hline & & Social worker(a) & 3.88 & .77 & \multirow{4}{*}{$\mathrm{p}=.282$} & \multirow{4}{*}{$.296(.829)$} \\
\hline & \multirow{3}{*}{$\begin{array}{l}\text { Organizational } \\
\text { commitment }\end{array}$} & Nurse(b) & 3.77 & .51 & & \\
\hline & & Nursing assistant(c) & 3.88 & .58 & & \\
\hline & & $\begin{array}{l}\text { Aged care facility } \\
\text { worker(d) }\end{array}$ & 3.76 & .60 & & \\
\hline
\end{tabular}

$* \mathrm{p}<.05, * * \mathrm{p}<.01, * * * \mathrm{p}<.001$

\subsubsection{Difference in Emotional Labor and Job Attitude by Facility Type}

Variance analysis was conducted to examine the difference in emotional labor and job attitude by the facility type of aged care facility workers. The equality of variance was assumed as Levene's test was $\mathrm{p}=.110 \sim .169$ for emotional labor and $\mathrm{p}=.112 \sim .200$ for job attitude. In the difference in emotional labor by the facility type of aged care facility workers, a statistically significant difference was found between the short-term facility group and the day care, nursing home group for the frequency of emotional display ( $\mathrm{t}=3.629, \mathrm{p}<.05)$, but there was no statistically significant difference found for the attentiveness to display rules $(\mathrm{t}=1.260, \mathrm{p}>.05)$ and emotional dissonance $(\mathrm{t}=.273, \mathrm{p}>.05)$. On the other hand, there was no statistically significant difference in mean found between groups for job attitude in both job satisfaction ( $\mathrm{t}=1.244, \mathrm{p}>.05)$ and organizational commitment $(\mathrm{t}=.655, \mathrm{p}>.05)$. There was a meaningful difference in the frequency of emotional display of aged care facility workers with short-term facility group demonstrating the highest mean, and the fact that there is no difference in mean for the attentiveness to display rules and emotional dissonance, which are sub-factors of emotional labor, and job satisfaction and organizational commitment, which are sub-factors of job attitude, implies that it is 
at the same level regardless of facility type. The results of examining the difference in emotional labor and job attitude by the facility type of aged care facility workers are shown in [Table 9].

[Table 9] Difference in Emotional Labor and Job Attitude by Facility Type

\begin{tabular}{|c|c|c|c|c|c|c|}
\hline \multicolumn{3}{|c|}{ Classification } & M & SD & Levene test & $\mathrm{F}(\mathrm{p})$ \\
\hline \multirow{9}{*}{$\begin{array}{l}\text { Emotiona } \\
1 \text { labor }\end{array}$} & \multirow{3}{*}{$\begin{array}{c}\text { Frequency of } \\
\text { emotional } \\
\text { display }\end{array}$} & $\begin{array}{l}\text { Day care } \\
\text { facility(a) }\end{array}$ & 3.35 & .94 & \multirow{3}{*}{$\mathrm{p}=.168$} & \multirow{3}{*}{$\begin{array}{c}3.629 *(.029) \\
b>a, c\end{array}$} \\
\hline & & $\begin{array}{l}\text { Short-term care } \\
\text { facility(b) }\end{array}$ & 3.66 & .81 & & \\
\hline & & Nursing home(c) & 2.33 & .47 & & \\
\hline & \multirow{3}{*}{$\begin{array}{c}\text { Attentiveness } \\
\text { to display } \\
\text { rules }\end{array}$} & $\begin{array}{l}\text { Day care } \\
\text { facility(a) }\end{array}$ & 3.10 & .82 & \multirow{3}{*}{$\mathrm{p}=.110$} & \multirow{3}{*}{$1.260(.303)$} \\
\hline & & $\begin{array}{l}\text { Short-term care } \\
\text { facility(b) }\end{array}$ & 3.26 & .26 & & \\
\hline & & Nursing home(c) & 2.60 & .82 & & \\
\hline & \multirow{3}{*}{$\begin{array}{l}\text { Emotional } \\
\text { dissonance }\end{array}$} & $\begin{array}{l}\text { Day care } \\
\text { facility(a) }\end{array}$ & 2.66 & .90 & \multirow{3}{*}{$\mathrm{p}=.169$} & \multirow{3}{*}{$.273(.761)$} \\
\hline & & $\begin{array}{l}\text { Short-term care } \\
\text { facility (b) }\end{array}$ & 2.76 & 1.14 & & \\
\hline & & Nursing home(c) & 2.40 & .54 & & \\
\hline \multirow{6}{*}{$\begin{array}{c}\text { Job } \\
\text { attitude }\end{array}$} & \multirow{3}{*}{$\begin{array}{c}\text { Job } \\
\text { satisfaction }\end{array}$} & $\begin{array}{c}\text { Day care } \\
\text { facility(a) }\end{array}$ & 3.52 & .41 & \multirow{3}{*}{$\mathrm{p}=.200$} & \multirow{3}{*}{$1.244(.291)$} \\
\hline & & $\begin{array}{c}\text { Short-term care } \\
\text { facility(b) }\end{array}$ & 3.68 & .83 & & \\
\hline & & Nursing home(c) & 3.30 & .27 & & \\
\hline & \multirow{3}{*}{$\begin{array}{c}\text { Organizational } \\
\text { commitment }\end{array}$} & $\begin{array}{c}\text { Day care } \\
\text { facility(a) }\end{array}$ & 3.81 & .62 & \multirow{3}{*}{$\mathrm{p}=.112$} & \multirow{3}{*}{$.655(.521)$} \\
\hline & & $\begin{array}{l}\text { Short-term care } \\
\text { facility(b) }\end{array}$ & 3.80 & .80 & & \\
\hline & & Nursing home(c) & 3.48 & .07 & & \\
\hline
\end{tabular}

\section{Conclusion and Suggestions}

This study investigated the differences in emotional labor and job attitude of aged care facility workers by their sociodemographic characteristics. The following discussions are based on the results of the analysis.

First, upon examining the differences in emotional labor by the sociodemographic characteristics of aged care facility workers, there was a meaningful difference between groups for facility type, but no difference was found between groups for gender, age, and job position. The equality of variance was assumed as Levene's test was $\mathrm{p}=.055 \sim .093$ for emotional labor and $\mathrm{p}=.220 \sim .298$ for job attitude. There was no statistically significant difference in emotional labor by the gender of aged care facility worker in the frequency of emotional display $(t=.397, p>.05)$, the attentiveness to display rules $(t=.229, p>.05)$ and emotional dissonance ( $\mathrm{t}=.845, \mathrm{p}>.05)$. There was also no difference in means under the level of statistical significance in job attitude for both job satisfaction $(t=1.543, p>.05)$ and organizational 
commitment $(t=1.781, p>.05)$. In job attitude, a statistically significant difference was found between groups in the 40's and the 50's and over for job satisfaction $(\mathrm{t}=3.955, \mathrm{p}>.05)$, but there was no statistically significant difference found between groups in the difference in mean for organizational commitment $(\mathrm{t}=1.781, \mathrm{p}>.05)$. There was a meaningful difference in the job satisfaction of aged care facility workers between groups in the 40's and the 50's and over, and the fact that there is no difference in mean for emotional labor and job attitude implies that it is at the same level regardless of age. In facility type, short-term facility workers showed the highest frequency of emotional display and nursing home workers had a relatively low frequency. On the other hand, the attentiveness to display rules and emotional dissonance, which are sub-factors of emotional labor, were found to be at the same level with no difference in mean, regardless of gender, age, and job position.

Second, upon examining the differences in job attitude by the sociodemographic characteristics of aged care facility workers, there was a meaningful difference between groups for age, but no difference was found between groups for gender, job position, and facility type. The equality of variance was assumed as Levene's test was $\mathrm{p}=.065 \sim .211$ for emotional labor and $\mathrm{p}=.282 \sim .844$ for job attitude. There was no statistically significant difference in emotional labor by the job position of aged care facility worker in the frequency of emotional display $(\mathrm{t}=1.653, \mathrm{p}>.05)$, the attentiveness to display rules $(\mathrm{t}=1.578, \mathrm{p}>.05)$ and emotional dissonance $(\mathrm{t}=1.394, \mathrm{p}>.05)$. There was also no difference in means under the level of statistical significance in job attitude for both job satisfaction $(\mathrm{t}=.873, \mathrm{p}>.05)$ and organizational commitment ( $\mathrm{t}=.296, \mathrm{p}>.05)$. The equality of variance was assumed as Levene's test was $\mathrm{p}=.110 \sim .169$ for emotional labor and $\mathrm{p}=.112 \sim .200$ for job attitude. In the difference in emotional labor by the facility type of aged care facility workers, a statistically significant difference was found between the short-term facility group and the day care, nursing home group for the frequency of emotional display ( $\mathrm{t}=3.629, \mathrm{p}<.05)$, but there was no statistically significant difference found for the attentiveness to display rules $(\mathrm{t}=1.260, \mathrm{p}>.05)$ and emotional dissonance $(\mathrm{t}=.273, \mathrm{p}>.05)$. On the other hand, there was no statistically significant difference in mean found between groups for job attitude in both job satisfaction ( $\mathrm{t}=1.244, \mathrm{p}>.05)$ and organizational commitment $(\mathrm{t}=.655, \mathrm{p}>.05)$. In age, the 40's showed the highest job satisfaction, and there was a meaningful difference in mean between the 40's group and the 50's and over group. On the other hand, in job attitude, job satisfaction was found to be at the same level with no difference in mean regardless of gender, job position and facility type, and organizational commitment were found to be at the same level with no difference in mean regardless of gender, age, job position and facility type.

As discussed above, this study seeks to provide foundational data for the development of programs to strengthen the capabilities of aged care facility workers in the field of social welfare services by identifying the differences in emotional labor and job attitude in aged care facility workers. Thus, this serves as an opportunity to resolve the emotional labor of workers and promote healthy job attitude.

Differences in the sociodemographic characteristics and emotional labor of aged care facility workers in $\mathrm{K}$ and $\mathrm{D}$ areas were significantly identified among groups in the type of facility. Nevertheless, this study is only limited to some of the elderly facility workers in K and D cities. The development of capacity-building programs for aged care facility workers with emotional labor is required, as well as further research for foundational data on successful job attitude and roles.

\section{References}

[1] So Jeong Kim, The Study on Job Satisfaction of Care Workers Between Long Term and Home Base Care Service Center, Journal of the Korean Association for Social Service, (2018), Vol.8, No.2, pp.49-70.

[2] W. Y. Jeong, Influence of psychological capital of care workers on job satisfaction : mediating effect of communication ability and job stress, Graduate School of Seoul Hanyoung University, Doctoral Dissertation, (2018) 
[3] Mi hyang Kim, Hyunjean Yi, An Inquiry in the relationship between parent and private kindergarten teachers -From the perspective of emotional labor, Journal of Parent Education, (2016), Vol.8, No.1, pp.79-104.

[4] J. M. Barbalet, Emotions and Sociology, 1st edition, Wiley-Blackwell, (2002)

[5] Hochschild, R. Arlie, The managed heart, The University of California Press, (1983)

[6] Sang Ki Min, Jong Woo Kim, The Causal Relationship among Educational Satisfaction, Competency and Job Satisfaction of Meister School Graduates, The Journal of Vocational Education Research, (2016), Vol.35, No.2 pp.1736.

[7] Blake E Ashforth, Ronald H. Humphrey, Emotional Labor in Service Roles: The Influence of Identity, The Academy of Management Review, (1993), Vol.18, No.1, pp.88-115.

[8] Don Hellriegel, John W. Slocum, Richard W. Woodman, Organizational behavior, St. Paul: West Pub.Co, (1989)

[9] Hyun-Soo Cha, A Study on the Effects of the Service Leadership of the Line Manager on Employees' Work Attitude and Service Performance, Kyong Gi University, Doctoral Dissertation, Unpublished, (2004)

[10] K. D. Hwang, Y. Y. Kim, Development of measurement tools and empirical verification of the effect of shift work schedule on the attitude of members of the organization, Journal of Industrial Relations, (1994), Vol.5, No.1, pp.51-65, https://hdl.handle.net/10371/29993

[11] H. J. Park, A study on the influence of the emotional labor on the employee burnout in the hotel industry, Konggi University, Master's Thesis, Unpublished, (2001)

[12] Yu Ra Lee, Sung Hwa Hong, An Effect of the Emotional Labor on the Burnout and the Job Satisfaction of the Hotel Employees, Tourism Research, (2010), Vol.25, No.1, pp.185-203.

[13] J. P. Kim, Effects of Emotional Labor of social workers in facilities for the disabled on the job performance - focusing on the mediating effect of Burnout, Department of Education Dongbang Culture University, Doctoral Dissertation, (2016)

[14] J. M. Yang, Effect on the Job Attitude and Turnover Intention for Job Stress of Care Helper Focusing on Moderate Variables of Professional Consciousness, Department of Social Welfare Hanyoung Theological University, Doctoral Dissertation, (2016) 